\title{
Studying the Adsorption Properties of Modified Red Mud towards Phosphate Removal from its Solutions
}

\author{
Ahmed M. Yousif, Michael Rodgers, and Eoghan Clifford
}

\begin{abstract}
The effect of activation and heat treatment of row red mud (a residue from bauxite refining) on the adsorption of phosphate $\left(\mathrm{PO}_{4}-\mathrm{P}\right)$ from its solutions was studied in parallel experiments. Effect of time, temperature, concentration of adsorbate was studied using batch experiments. The adsorption of phosphate follows Langmuir better than Freundlich adsorption isotherm. Reprecipitated and calcined red mud was found to be the most efficient activation processes for the raw red mud. These findings can be extended to the treatment of industrial effluents containing phosphates like that from phosphatic fertilizer plants.
\end{abstract}

Index Terms-Adsorption, red mud, $\mathrm{PO}_{4}-\mathrm{P}$, wastewaters.

\section{INTRODUCTION}

Red mud is an insoluble residue produced when refining of bauxite to finally obtain pure aluminum. Red mud, due to its high aluminum, iron, and calcium content, has been suggested as a cheap adsorbent for removal of toxic metals (e.g., As, $\mathrm{Cr}, \mathrm{Pb}, \mathrm{Cd}$ ) as well as for water or wastewater treatment. The basic advantage of red mud is its versatility in application. Since it is composed of a mixture of useful adsorbents and flocculants, it can be used for treatment of several effluents [1]

Phosphates and nitrates are usually added to the soil in the form of fertilizers to enhance plant growth. Large concentrations of these anions in wastewaters are considered as a great hazard to human beings, they also contribute to high BOD levels that they cause plant life and algae to grow quickly in different waters. When algae grow quickly, they also die quickly. This contributes to the organic waste in the water, which is then decomposed by bacteria and then dissolved oxygen (DO) levels decrease. Since less dissolved oxygen is available in the water, fish and other aquatic organisms may not survive.

In order to eliminate the possible dangers to receiving water sources, it is necessary to treat before discharge. Adsorption of phosphate from aqueous solution has been studied in the past few decades by several authors using different adsorbents, like activated alumina [2], half-burnt dolomite [3], activated carbon [4,5], coconut shell carbon [6], clays [7], bentonite [8], ferrihydrite [9], goethite [10], and hematite [11].

Manuscript received April 25, 2012; revised July 5, 2012.

Ahmed M. Yousif is with the Department of Chemistry, Faculty of Science, Minufiya University, Egypt (e-mail: amm_yousif_000@ hotmail.com).

Michael Rodgers is with Civil Engineering, National University of Ireland, Galway, Ireland (e-mail: Michael.rodgers@nugalway.ie).

Eoghan Clifford is with Civil Engineering, National University of Ireland, Galway, Ireland (e-mail: eoghan.clifford@nugalway.ie).
In recent years, considerable attention has been paid based on economic and environmental concerns to the study of using red mud (RM) [12,13] as alternative adsorbents for sorption of phosphate from water.

In the present paper, removal of phosphate from aqueous solution using the raw RM and its active forms prepared by different chemical and thermal methods were studied in batch equilibration technique. The influences of time and initial phosphate concentration on the sorption capacity were investigated. The isotherm sorption experiments were also conducted.

\section{EXPERIMENTAL}

\section{A. Materials}

Raw red mud (RM) samples used in the present study were obtained from bauxite refining factories, Ireland. RM was activated with different procedures as will be described in the following section. $\mathrm{K}_{2} \mathrm{HPO}_{4}$ is used as a source of $\mathrm{PO}_{4}-\mathrm{P}$. All the other used chemicals are Aldrich products.

\section{B. Textural Properties of Red Mud}

Particle size analysis was performed by using different sieves with different diameters $(5,3.36,2,1.18,1 \mathrm{~mm})$ and $(600,425,300,250,150,63 \mu \mathrm{m})$ and the results were listed in Table I.

\section{Activation of Washed Red Mud \\ 1) By calcination}

Washed red mud samples placed in porcelain dishes were heat-treated at $700^{\circ} \mathrm{C}$ for 2 hours in an oven. The powder was stirred once during the heat treatment. It is a fact that the optimum conditions of temperature and time for the calcinations process to remove $\mathrm{PO}_{4}-\mathrm{P}$ from its solutions are $700^{\circ} \mathrm{C}$ and 2 hours, respectively [14]. If we calcine red mud at lower temperature or time, the surface area will be comparatively less, also it will be less efficient as temperatures are increased or time is prolonged. That is because of the decomposition of some hydroxyl groups and the shrinkage of materials.

2) By adding additives

Because of the high sodium content and alkalinity of the red mud [13], we treated the red mud with adding $8 \%(\mathrm{w} / \mathrm{w})$ anhydrous $\mathrm{CaSO}_{4}$ to each of raw and calcined red mud in order to: i) reduce the $\mathrm{pH}$ to nearly $\mathrm{pH} 8$ at solid/water ratio of 1:2.5 (the most desired $\mathrm{pH}$ for $\mathrm{PO}_{4}-\mathrm{P}$ adsorption on red mud as will be discussed later on). ii) to make probable calcium sulphate complex which is preferable also at this range of $\mathrm{pH}$.

3) By reprecipitation of dissolved red mud

Procedure was described by Kerry C. et al [15] by 
dissolving red mud in $\mathrm{HCl}$ on heating and reprecipitating it using $\mathrm{NH}_{4} \mathrm{OH}$ till acquiring $\mathrm{pH}$ 8. The activated red mud was filtered and washed thoroughly with distilled water and dried over night at $100^{\circ} \mathrm{C}$ then calcined at $500^{\circ} \mathrm{C}$ for 2 hours.

\section{Batch Experiments}

Sorption studies were carried out by shaking $250 \mathrm{ml}$ of 20 $\mathrm{mg} / 1 \mathrm{~K}_{2} \mathrm{HPO}_{4}$ (as $\mathrm{PO}_{4}-\mathrm{P}$ ) solution at $250 \mathrm{rpm}$ with $2 \mathrm{~g}$ of reprecipitated red mud or $15 \mathrm{~g}$ of the rest examined red mud samples individually in the bottles capped with plastic screws for $48 \mathrm{~h}$. After equilibrium, the samples were centrifuged for 5 min and a clear aliquot of the supernatant was taken and analyzed for phosphate concentration. The amount of phosphate adsorbed per unit of adsorbents $(\mathrm{X})$ as calculated by:

$$
X=(C i-C f) \mathrm{v} / \mathrm{m}
$$

where $\mathrm{X}$ is the amount of the phosphate adsorbed, $\mathrm{Ci}$ and $\mathrm{C}_{\mathrm{f}}$ are the initial and final concentrations of $\mathrm{PO}_{4}-\mathrm{P}$ in solution in $\mathrm{mg} / \mathrm{l}$, respectively, $\mathrm{V}$ is the solution volume in liters, and $\mathrm{m}$ is the mass of sorbent in $\mathrm{g}$.

The effect of time on the removal of $\mathrm{PO}_{4}-\mathrm{P}$ was also investigated for increasing periods of time, until equilibrium was achieved.

The sorption isotherm indicates the distribution of adsorbate molecules between the liquid phase and the solid phase when the sorption process reaches an equilibrium state. Solutions of different initial concentrations 5, 10, 20, 30 and $40 \mathrm{mg} / \mathrm{PO}_{4}-\mathrm{P}$ were used to investigate the effect of concentration on the $\mathrm{PO}_{4}-\mathrm{P}$ removal by $15 \mathrm{~g}$ of washed red mud in $250 \mathrm{ml}$ of solution for $20 \mathrm{~h}$.

\section{RESULTS AND DISCUSSION}

Table I shows the particle size analysis for each type of red mud.

TABLE I: PARTICLE SIZE ANALYSIS FOR EACH TYPE OF RED MUD

\begin{tabular}{|c|c|c|c|c|}
\hline \multirow{2}{*}{$\begin{array}{l}\text { Pan } \\
\text { diameter }\end{array}$} & \multicolumn{4}{|c|}{ Mass retained on each pan } \\
\hline & $\begin{array}{c}\text { precipitated } \\
\text { RM }\end{array}$ & $\begin{array}{c}\text { Raw RM+ } \\
\mathbf{8 \%} \\
\mathrm{CaSO}_{4} \\
\end{array}$ & $\begin{array}{c}\text { Calcined } \\
\text { RM }\end{array}$ & $\begin{array}{l}\text { Calcined RM } \\
+8 \% \mathrm{CaSO}_{4}\end{array}$ \\
\hline $5 \mathrm{~mm}$ & 0 & 0 & 0 & 0 \\
\hline $3.36 \mathrm{~mm}$ & 0 & 0 & 0 & 0 \\
\hline $2 \mathrm{~mm}$ & 0 & 0 & 0 & 0 \\
\hline $1.18 \mathrm{~mm}$ & 0.27 & 0.59 & 0.16 & 0.06 \\
\hline $1 \mathrm{~mm}$ & 0.16 & 0.27 & 0.17 & 0.11 \\
\hline $600 \mu \mathrm{m}$ & 1.49 & 2.85 & 1.76 & 1.56 \\
\hline $425 \mu \mathrm{m}$ & 1.99 & 4.32 & 3.37 & 3.49 \\
\hline $300 \mu \mathrm{m}$ & 2.91 & 5.57 & 6.73 & 5.92 \\
\hline $250 \mu \mathrm{m}$ & 1.61 & 1.87 & 2.57 & 2.24 \\
\hline $150 \mu \mathrm{m}$ & 4.75 & 3.16 & 3.95 & 3.89 \\
\hline $63 \mu \mathrm{m}$ & 3.66 & 0.93 & 0.89 & 1.95 \\
\hline Base & 2.94 & 0.48 & 0.17 & 0.87 \\
\hline
\end{tabular}

It is clear that the precipitated RM possesses the smallest average particle diameter and so the highest exposed surface area. This finding may explain its higher adsorption capacity towards PO4-P if compared with the other examined forms of red mud as will be shown later on.

Table II shows the combined data obtained during the examination of the effect of time batch experiments towards adsorption of $\mathrm{PO}_{4}-\mathrm{P}$ by different $\mathrm{RM}$ samples.

TABLE II: EFFECT OF TIME BATCH EXPERIMENTS TOWARDS ADSORPTION OF $\mathrm{PO}_{4}$-P BY DIFFERENT RM SAMPLES

\begin{tabular}{|c|c|c|c|c|c|}
\hline \multicolumn{2}{|c|}{$\begin{array}{l}\text { Using } 15 \\
\mathrm{~g} \text { in } 250 \\
\mathrm{ml} \\
\text { solution } \\
\end{array}$} & SAMPLE A & SAMPLE B & SAMPLE C & SAMPLE D \\
\hline \multicolumn{2}{|c|}{$\begin{array}{l}\text { Initial pH } \\
=7.5\end{array}$} & $\begin{array}{l}\text { Raw RM+ } \\
8 \% \mathrm{CaSO}_{4}\end{array}$ & $\begin{array}{c}\text { Calcined } \\
\text { RM }\end{array}$ & $\begin{array}{c}\text { Calcined } \\
\mathrm{RM}+\mathbf{8 \%} \% \\
\mathrm{CaSO}_{4}\end{array}$ & $\begin{array}{l}\text { Using } 2 \text { g of } \\
\text { precipitated } \\
\text { red mud }\end{array}$ \\
\hline \multirow{10}{*}{ 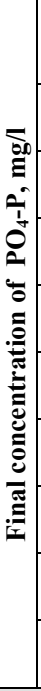 } & $\begin{array}{l}t=5 \\
\min \end{array}$ & $\begin{array}{l}17.74 \\
(0.39)\end{array}$ & $\begin{array}{c}2.74 \\
(0.32)\end{array}$ & $\begin{array}{c}5.31 \\
(0.45)\end{array}$ & $\begin{array}{l}16.85 \\
(0.52)\end{array}$ \\
\hline & $\mathbf{t}=\mathbf{1 ~ h}$ & $\begin{array}{l}15.13 \\
(0.45)\end{array}$ & $\begin{array}{c}0.77 \\
(0.16)\end{array}$ & $\begin{array}{c}3.12 \\
(0.17)\end{array}$ & $\begin{array}{c}9.74 \\
(0.33)\end{array}$ \\
\hline & $\mathbf{t}=\mathbf{2} \mathbf{h}$ & $\begin{array}{l}13.35 \\
(0.38)\end{array}$ & $\begin{array}{c}0.31 \\
(0.08)\end{array}$ & $\begin{array}{c}2.06 \\
(0.13)\end{array}$ & $\begin{array}{c}8.02 \\
(0.32)\end{array}$ \\
\hline & $\mathbf{t}=\mathbf{3} \mathbf{h}$ & $\begin{array}{l}12.63 \\
(0.55)\end{array}$ & $\begin{array}{c}0.20 \\
(0.11)\end{array}$ & $\begin{array}{c}1.69 \\
(0.04)\end{array}$ & $\begin{array}{c}7.46 \\
(0.04)\end{array}$ \\
\hline & $\begin{array}{c}t=18 \\
h\end{array}$ & $\begin{array}{l}10.03 \\
(0.25)\end{array}$ & $\begin{array}{c}0.11 \\
(0.06)\end{array}$ & $\begin{array}{c}0.78 \\
(0.03)\end{array}$ & $\begin{array}{c}6.61 \\
(0.32) \\
\end{array}$ \\
\hline & $\begin{array}{c}t=19 \\
h\end{array}$ & $9.94(0.21)$ & $\begin{array}{c}0.12 \\
(0.05)\end{array}$ & $\begin{array}{c}0.58 \\
(0.03)\end{array}$ & $\begin{array}{c}6.12 \\
(0.20)\end{array}$ \\
\hline & $\begin{array}{c}\mathbf{t}=20 . \\
5 \mathrm{~h}\end{array}$ & $\begin{array}{l}10.04 \\
(1.05)\end{array}$ & $\begin{array}{c}0.12 \\
(0.07)\end{array}$ & $\begin{array}{c}0.57 \\
(0.02)\end{array}$ & $\begin{array}{c}5.75 \\
(0.08)\end{array}$ \\
\hline & $\begin{array}{c}\mathbf{t}=22 . \\
\mathbf{0 ~ h}\end{array}$ & $9.45(0.65)$ & $\begin{array}{c}0.12 \\
(0.05) \\
\end{array}$ & $\begin{array}{c}0.55 \\
(0.01) \\
\end{array}$ & $\begin{array}{c}6.39 \\
(0.59) \\
\end{array}$ \\
\hline & $\begin{array}{c}\mathrm{t}=24 \\
\mathrm{~h}\end{array}$ & $9.12(0.21)$ & - & $\begin{array}{c}0.55 \\
(0.02) \\
\end{array}$ & $\begin{array}{r}6.00 \\
(0.19) \\
\end{array}$ \\
\hline & $\begin{array}{c}t=48 \\
h\end{array}$ & $8.99(0.08)$ & - & $\begin{array}{c}0.54 \\
(0.04)\end{array}$ & - \\
\hline \multicolumn{2}{|c|}{$\mathrm{q}_{\mathrm{e}}, \mathrm{mg} / \mathrm{g}$} & 0.184 & 0.331 & 0.324 & 1.750 \\
\hline
\end{tabular}

Standard deviation shown in parentheses.

It is obvious that reprecipitated RM possesses the highest uptake capacity $(1.75 \mathrm{mg} / \mathrm{g})$ among others because of the larger exposed surface area along with the applied chemical modification during the reprecipitation process.

Table III shows the effect of concentration on the $\mathrm{PO}_{4}-\mathrm{P}$ removal along with the values of Langmuir constants using the same conditions followed with sample B. Langmuir isotherm is defined as follows:

$$
C_{f} / \mathrm{q}_{e}=\mathrm{C}_{f} / \mathrm{q}_{s}+1 /\left(K_{L} q_{s}\right)
$$

where $C_{f}$ is the equilibrium concentration of adsorbate in solution after adsorption, $(\mathrm{mg} / \mathrm{l}), q_{e}$ is the mass of adsorbate adsorbed per unit mass of adsorbent, ( $\mathrm{mg}$ adsorbate/g red mud), $\mathrm{q}_{\mathrm{s}}$ is the maximum capacity ( $\mathrm{mg}$ adsorbate/g red mud), $K_{L}$ is an empirical constant. By plotting $C_{f} / q_{e}$ against $C_{f}$, the slope $1 / q_{s}$ and the intercept $1 /\left(K_{L} q_{s}\right)$ can be calculated. Freundlich isotherm is defined as follow:

$$
\log \mathrm{q}_{e}=\log \mathrm{K}_{f}+1 / \mathrm{n} \log C_{e}
$$

where $q_{e}=$ the mass of adsorbate adsorbed per unit mass of adsorbent, (mg adsorbate/g red mud), $K_{f}$ is the Freundlich capacity factor, $1 / \mathrm{n}$ is the Freundlich intensity parameter, $C_{e}$ $=$ equilibrium concentration of adsorbate in solution after adsorption, (mg/l). The constants can be determined by plotting, on a log scale, qe against $\mathrm{C}_{e}$. 
TABLE III: EFFECT OF CONCENTRATION ON THE UPTAKE OF PO- 4 P USING

\begin{tabular}{|c|c|c|c|c|c|}
\hline $\begin{array}{c}C_{i}, \\
m g / L\end{array}$ & $\mathrm{C}_{\mathrm{f}}, \mathrm{mg} / \mathrm{L}$ & $\mathbf{q}_{\mathrm{e}}, \mathrm{mg} / \mathrm{g}$ & $\mathbf{C}_{\mathrm{f}} / \mathbf{q}_{\mathrm{e}}$ & $\begin{array}{c}\mathbf{K}_{\mathrm{L}}, \\
\mathbf{1} \mathbf{m g}\end{array}$ & $\begin{array}{c}\mathbf{q}_{\mathrm{s}}, \\
\mathrm{mg} / \mathrm{g}^{*}\end{array}$ \\
\hline 5 & $\begin{array}{c}0.27 \\
(0.05)\end{array}$ & 0.079 & 3.42 & \multirow{5}{*}{0.819} & \multirow{5}{*}{0.558} \\
\hline 10 & $\begin{array}{c}0.36 \\
(0.05) \\
\end{array}$ & 0.161 & 2.24 & & \\
\hline 20 & $\begin{array}{c}1.06 \\
(0.16)\end{array}$ & 0.320 & 3.31 & & \\
\hline 30 & $\begin{array}{c}5.28 \\
(0.55) \\
\end{array}$ & 0.412 & 12.82 & & \\
\hline 40 & $\begin{array}{c}9.43 \\
(0.53)\end{array}$ & 0.511 & 18.49 & & \\
\hline
\end{tabular}

*Calculated from Langmuir equation

Both isotherms were plotted as shown in Fig. 1 as illustrated below.
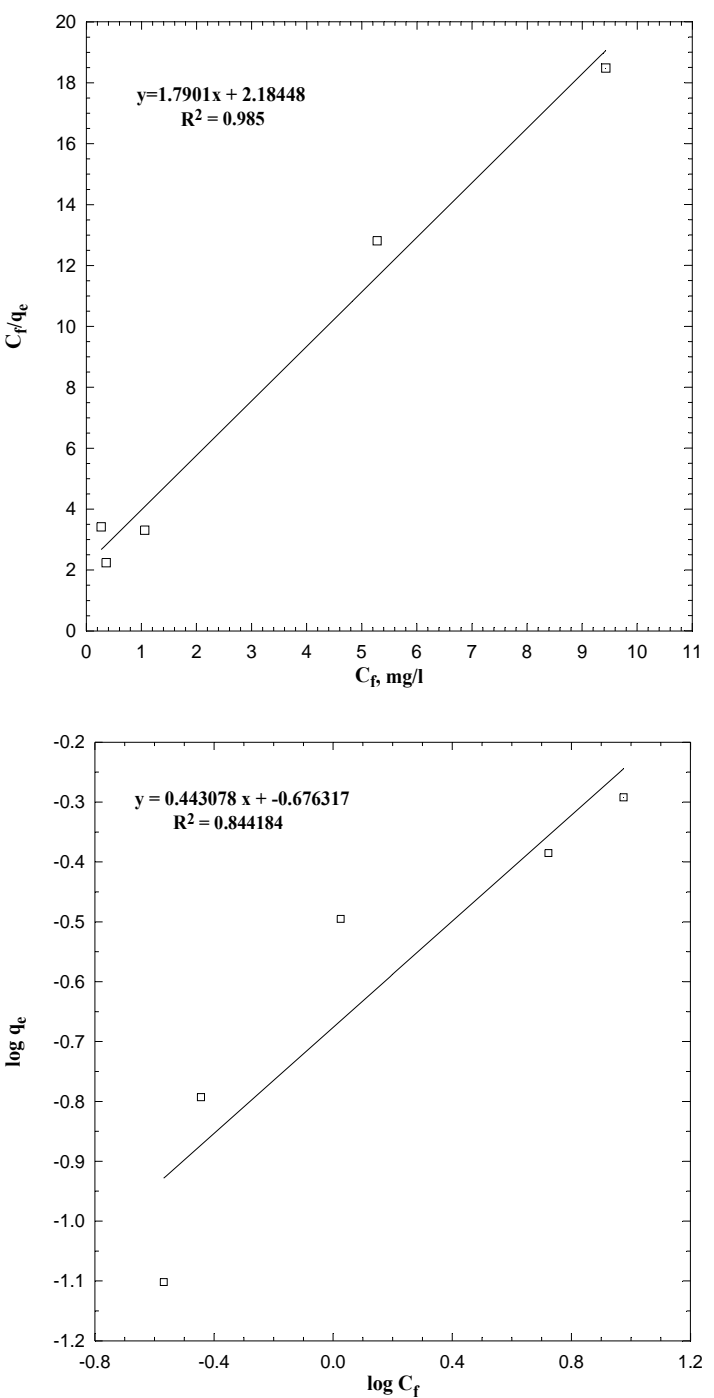

Fig. 1. Langmuir and freundlich isotherms of $\mathrm{PO}_{4}-\mathrm{P}$ adsorption

It was found that the Langmuir isotherm was more suitable. That is because of the comparative better $\mathrm{R}^{2}$ value for Langmuir plot $\left(\mathrm{R}^{2}=0.985\right)$ if compared with that of Freundlich plot $\left(\mathrm{R}^{2}=0.844\right)$. Moreover, $\mathrm{q}_{\mathrm{s}}$ value for Langmuir plot was found to be consistent with the experimental data obtained when using high concentrations of $\mathrm{PO}_{4}-\mathrm{P}$.

\section{CONCLUSION}

Reprecipitated and calcined red mud was found to be the most efficient activation processes for the raw red mud. Reprecipitated RM possesses the smallest average particle diameter and so the highest exposed surface area. This finding may explain its higher adsorption capacity towards $\mathrm{PO}_{4}-\mathrm{P}$ if compared with the other examined forms of red mud. Langmuir isotherm was found to be more suitable than Freundlich isotherm. That is because of the comparative better $\mathrm{R}^{2}$ value for Langmuir plot $\left(\mathrm{R}^{2}=0.985\right)$ if compared with that of Freundlich plot $\left(\mathrm{R}^{2}=0.844\right)$. Moreover, $\mathrm{q}_{\mathrm{s}}$ value for Langmuir plot was found to be consistent with the experimental data obtained at high concentrations. These findings can be extended to the treatment of industrial effluents containing phosphates like that from phosphatic fertilizer plants.

\section{REFERENCES}

[1] Pradhan, J. Das, S. Das, and R, S. Thakur, "Adsorption of phosphate from aqueous solution using activated red mud," J. Colloid Interface Sci., vol. 204, pp. 169-172, 1998.

[2] H. Brattebo, and K. Odegaard, "The influence of different substrates on enhanced chemical phosphorus removal in a sequencing batch reactor," J. Water Res., vol. 20, pp. 977-981, 1986.

[3] H. Roques, N. Jeddy, and A. Libuglf, "Phosphorus removal from wastewater by half-burned dolomite," Water Res., vol. 25, pp. 959-965, 1991.

[4] K.J Koh and G. J Chung, "Phosphorus removal and recovery technologies," Hwahok Kanghok, vol. 23, pp. 303-308, 1998.

[5] D. S. Bhargava, and S. B. Sheldarkar, "Removal of phosphate from its solutions using activated carbon," J. Environ. Pollut, vol. 76, pp. 51-56, 1972.

[6] K. Palanivelu, and N. Elangovan, "Removal of Phosphorus from solutions using coconut shell carbon," Indian J. Environ. Prot., vol. 14, pp. 688-695, 1994

[7] I. Fox, "Using different caly types in phosphate removal processes," $J$. Chem. Technol. Biotechnol., vol. 57, pp. 97-101, 1993.

[8] E. Gonzalez-Pradas, M.V. Sanchez, and G.A. allego Campo, "Removal of Phosphorus from aqueous solutions using bentonite as an adsorbent," J. Chem. Technol. Biochenol. Vol. 54, pp. 291-297, 1992.

[9] D. Hawka, P. D. Carpenter, and K. A. Hunter, "Synthetic routes for preparation of good adsorbents for phosphorus removal." Environ. Sci. Technol., vol. 23, pp. 187-191, 1989.

[10] R. L Parfitt, "Studying the adsorption properties of goethite towards phosphorus and nitrogen removal," J. Soil Sci. vol. 40, pp. 359, 1989.

[11] C. Colombo, V. Barren, and J. Torrent, "Using hematite in phosphate removal from its waste streams," Geochim. Cosmochim. Acta, vol. 58, pp.1261-1266, 1994.

[12] S. J. Shiao and K. Akashi, "Red mud material and its use in wastewater purification," J. WPCF vol. 49, pp. 280-285, 1997.

[13] E. L'opez, B. Soto, M. Arias, A.N'ũnez, D. Rubinos, and T. Barral, "Adsorbent properties of red mud and its use for wastewater treatmen," Water Res., vol. 32, pp. 1314-1322, 1998.

[14] Y. Li, C. Liu, Z. Luan, X. Peng, C. Zhu, Z, Chen, Z. Zhang, J. Fan, and $Z$. Jia , " Phosphorus removal from aqueous solutions using raw and activated red mud and fly ash," J. Hazard Mater., vol. 137, pp. 374-383, 2006.

[15] K. C. Pratt, V. Christoverson, "Reprecipitated red mud and its rule in phosphate removal," Fuel, vol. 61, pp. 460-462, 1982.

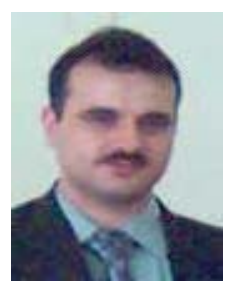

Ahmed Mohammed Mohammed Yousif was born on 9/3/1977 in Egypt. Currently, he is work as lecturer, Chemistry Department, Faculty of science, Menoufiya University, Egypt. He got PhD. on Physical Chemistry, Menoufiya University, 23/6/2008.

$\mathrm{He}$ made his military duty. $\mathrm{He}$ is a lecturer in chemistry department and he is interested in the field of wastewater treatment using natural and synthetic adsorbents. Kinetic and thermodynamic calculations may be performed using both batch and column techniques to examine the applicability of such studied adsorbents in the industrial field. 